\title{
intuitio
}

Revista do PPG em Filosofia da PUCRS

d= http://dx.doi.org/10.15448/1983-4012.2019.1.32184

\section{A STUDY OF BLACK SLAVERY IN THE FIRST TOME OF THE THESAURUS INDICUS BY DIEGO DE AVENDAÑO (1594-1698): IS HE A THEORIST CONTRARY TO TRADE OR SLAVERY?}

\author{
UM ESTUDO SOBRE A ESCRAVIDÃO NEGRA NO \\ PRIMEIRO TOMO DO THESAURUS INDICUS DE DIEGO DE \\ AVENDAÑO(1594-1698): SERIA ELE UM TEÓRICO CONTRÁRIO \\ AO COMÉRCIO OU A ESCRAVIDÃO?
}

\begin{abstract}
In the present text we attempt to highlight a few points in Avendaño's argumentation that allow us to consider that the personal Jesuit position would be contrary to the trafficking and trade of Ethiopian slaves that was done at the time, especially if we look at the criticisms he made against the authorities of his time. However, we will hold on that Avendaño did not condemn the institution of slavery as such, accepting certain fair titles of slavery, like other authors of his time. We propose the following path: first, Avendaño's analysis of the Molina and Sánchez positions; and second, Avendaño's own arguments on the subject. We will use the first volume of the Thesaurus Indicus, in particular: Title IX, ch. XII, § 8; where the author discusses the trade issue of Ethiopian slaves, text quoted in the secondary literature as essential to the treatment of black slavery.
\end{abstract}

Keywords: Didadicus de Avendaño; black slavery; trade; safe conscience.

\footnotetext{
1 Universidade Federal de Pelotas - UFPel. ORCID: http://orcid.org/0000-0002-0296-3877
} 
Resumo: No presente texto nós pretendemos ressaltar alguns pontos na argumentação de Avendaño que nos permite considerar que a sua posição pessoal era contrária ao tráfico e ao comércio de Escravos da Etiópia, especialmente quando olhamos para as críticas do jesuíta aos intelectuais do seu tempo. Contudo, nós pretemos sustentar aqui Diego de Avendaño não teria condenado a escravidão enquanto instituição, aceitando alguns títulos justos de escravidão, como a maioria dos autores do seu tempo. Para tanto: primeiro, apresentaremos a análise de Avendaño das posições de Molina e Sánchez; depois, os próprios argumentos de Avedaño sobre o tema. Neste estudo, iremos utilizar no primeiro volume do Thesaurus Indicus, particularmente no Título IX, cap. XII, §8, uma vez que esse particular trecho é onde o autor aborda o comércio dos escravos da Etíopia e citado na literatura secundária como essencial para o tratamento da escravidão negra.

Palavras-chave: Diego de Avendaño; escravidão negra; comércio; consciência segura.

\section{Introduction}

The negro' slavery subject with the hierocratic theory and the defense of Indian rights are the most known topics about Didadicus de Avendaño's thought ${ }^{2}$ on his Thesaurus Indicus ${ }^{3}$. With respect to black slavery, Avendaño's position appeared to have raised discussion with many

\footnotetext{
2 About Diego de Avendaño's life and works is important to see the Muñoz García's studies, particularly: Angél Muñoz García, "Introducción”, in: Diego de Avendaño, Thesaurus Indicus, Introducción, texto y Traducción de Ángel Muñoz García, Ediciones Universidad de Navarra, Pamplona 2001, p.13-53 [Colección de Pensamiento Medieval y Renacentista núm.16]; Ángel Muñoz García, Diego de Avendaño. Filosofía, moralidad, derecho y política en el Perú colonial, Fondo editorial de la UNMSM, Lima 2003, p.29-61.

3 Didacvs de Avendaño, Thesaurus Indicus seu Generalis Instructor pro regimine conscientiae, in iis quase ad Indias spectant. Tomus Primus, Ea continens, quae ad civilem praesertim conducunt Gubernationem. Antuerpiae. 1668. About the tomes that compose the Thesaurus, Muñoz García highlights: "en las referencias bibliográficas es frecuente catalogarlo como comprendido en seis tomos y editado en 1668-1686. En realidad, el Thesaurus propiamente tal está constituido por los dos primeros. [...]. Y los dos fueron publicados en Amberes, en un solo volumen, en 1668. A él se incorporaron posteriormente, como tomos II al VI, los cuatro volúmenes de un Actuarium Indicum" (2001, p.54). This incorporation happened at Amberes in the years 1675, 1676, 1678 and 1686 , respectively. For this study, I will use the critic edition of Thesaurus Indicus by Ángel Muñoz García and I will place the Latin text on footnote. I will concentrate only in the first volume and cite in this order: Thesaurus Indicus, Tome, title, chapter, paragraph (with the symbol $\S$ ) and the number of intern paragraph, according to the intern division made by Avendaño.
} 
authors since the $17^{\text {th }}$ century ${ }^{4}$. We know, for example, that Fray Epifanio de Moirans, in his Servi Liberi seu Naturalis Mancipiorum Libertatis Iusta Defensio (1682) dedicated many chapters to deal with the Jesuit position, namely: chapters VII-XI5. According to Losada, the Catholic bishop Grégoire $^{6}$, a famous French abolitionist of the $18^{\text {th }}$ century, identified the Jesuit Avendaño as a defender of slaves originating from the African continent, condemning the trade of slaves ${ }^{7}$. In the 19th century, Baron Humboldt said that Avendaño was not only against the trade of slaves but also he condemned slavery as a whole ${ }^{8}$. Ángel Losada, another authority on the colonial subject, highlighted that Avendaño was "undoubtedly one of the first voices, balanced and free of exaggeration, who rebelled against

4 Ángel Muñoz García in his paper "Diego de Avendaño y la Abolición de la Esclavitud" (2009) brings some considerations and testaments which highlight Avendaño's position. Look at: Ángel Muñoz García, "Diego de Avendaño y la Abolición de la Esclavitud”, Solar 5, (2009), 133-162.

5 Epifanio de Moirans, Servi Liberi seu Naturalis Mancipiorum Libertatis lusta Defensio, Consejo Superior de Investigaciones Científicas, Madrid, 2007.

6 Henri-Baptiste Grégoire (1750-1831), Archbishop of Blois (France), was a religious and French politician who has always been mobilized around major causes of humanity, such as: wrote against the death penalty; defender of the Jews' freedom; the situation of black slaves in the colonies and poor people in France. In addition, he dedicated to the Catholic Church of his time, seeking rearranges and fought against the atrocities that took place at the behest of the Spanish Inquisition. About black slavery he wrote intensely. Losada points out that: "su tesis (la misma que sostiene respecto de los judíos) es que las insuficiencias de los negros son resultado de su condición, no de su raza. Se refiere a muchos negros que se distinguieron en la historia: santos, generales, científicos y llega hasta a hablar del gran futuro de la música negra. Sobre el tema "la esclavitud" (y concretamente la de los negros) publica las siguientes obras: en 1813, De l'influence du Christianisme sur l'abolition de l'esclavage; en 1815, De la traite et de l'esclavage des noirs et blancs; en 1818, publica su Essai his torique sur les libertes de l'Eglise gallicane, donde expone su versión sobre el asunto del Concordato; en 1814, la que el considero como su gran obra: Histoire des sedes religieuses, que había sido confiscada por Fouchet, y en 1821, De l'influence du Christianisme sur les conditions desfemmes, obra en la que utiliza y cita como fuente, entre otros, los textos de Santa Teresa de Jesús" (1989, p.78). For more information of Henri-Baptiste Grégoire's work and thought look at: Ángel Losada, "El Abate Grégoire, Lector de los Humanistas y Juristas Españoles de los siglos XV a XVII Fuentes ideológicas españolas de la revolución francesa", Historia Mexicana 39 (1989), 71-88.

7 “Avendaño, jesuita, escribió valerosamente contra el comercio de los negros y se constituyó igualmente en defensor de los americanos. Él mismo declaró a los comerciantes de hombres que no se podía, con segura conciencia, esclavizar a los negros" (Ángel Losada, "El Abate Grégorie Lector de los Humanistas y Juristas Españoles..., op. cit., p.81).

8 “El escritor español Avendaño quizá es el primero que ha declamado con fuerza, no sólo contra el tráfico de los negros [...] sino también contra la esclavitud en general". In accord with Ángel Muñoz García, “Diego de Avendaño y la Abolición de la Esclavitud”, op. cit., p.135. 
Negro slavery, declaring that trade made by Europeans was unfair and immoral and violated the most sacred rights of nature"'. Recently, Ángel García Muñoz, the highest authority on the Avendaño's thought, has published a series of works ${ }^{10}$ in which he treats this theme of ownership, seeking to make Avendaño's position transparent.

However, this task is not free of difficulties. There are obstacles to overcome for any reader who wants to start the study of this author, namely: the Thesaurus was written in baroque Latin of the $17^{\text {th }}$ century and lack of studies about Avendaño"1". In addition to this, the text itself

\footnotetext{
9 "sin duda una de las primeras voces, equilibrada y libre de exageraciones, que se alza contra la esclavitud de los negros, al declarar que el comercio que de ellos hacían los europeos 'era injusto e inmoral y violaba los más sagrados derechos de la naturaleza'" (Ángel Losada, "EI Abate Grégorie Lector de los Humanistas y Juristas Españoles..., op. cit., p.81).

10 In special: Ángel Muñoz García, "Aristóteles; una sociedad imposible sin esclavitud", in: Diego de Avendaño, Corregidores, Encomenderos, Cabildos y Mercaderes. Thesaurus Indicus, vol. I, Tít. VI-IX, 2007, p.123-168; Ángel Muñoz García, "Diego de Avendaño y la Abolición de la Esclavitud", Solar 5, (2009), 133-162.

1 Thanks to the hard and brilliant work of translation and critical edition by Professor Ángel Muñoz García it is possible to see part of the Thesaurus (Tome I and part of tome II) in modern language (Spanish): Diego de Avendaño, Derecho, Consejo y Virreyes de Indias. Thesaurus Indicus, vol. I, Tít. I-III, Edición, introducción, texto y traducción de Ángel Muñoz García, Pamplona, Ediciones Universidad de Navarra, 2001. [Colección de pensamiento medieval y renacentista, núm. 16]. Diego de Avendaño, Oidores y oficiales de hacienda: Thesaurus Indicus, vol. I, Tít. IV y V, Volumen 1, Traducción Ángel Muñoz García, Pamplona, Ediciones Universidad de Navarra, 2003 [Colección de pensamiento medieval y renacentista, núm. 54]. Diego de Avendaño, Corregidores, encomenderos, cabildos y mercaderes. Thesaurus Indicus, vol. I, Tít. VI-IX, Traducción Ángel Muñoz García, Pamplona, Ediciones Universidad de Navarra, 2007 [Colección de pensamiento medieval y renacentista, núm.93]. In addition to the valuable introductions and critic' studies accompanying the publications. About the probabilism, Professor Luis Bacigalupo dedicated several works on it and its presence on the intellectual environment of colonial Peru, look at: Luis, Bacigalupo, "Las razones del probabilismo. Una exposición sucinta de sus fundamentos", Sílex, 3 (2014), 43-57. Luis Bacigalupo, "Probabilismo y modernidad", in: Fernando Armas Asín, (ed.), La construcción de la iglesia en los Andes, Pontificia Universidad Católica del Perú, Lima, 1999, p.257-300. In Brazil, Professor Roberto Pich, associate with Renata Floriano and Pablo Pimentel, published a insightful study about probabilism in Avendaño, namely: "Diego de Avendaño sobre a opinião provável - Tradução e edição simplifi cada de Diego de Avendaño S.J. (1594-1688), Auctarium Indicum seu Tomus Tertius ad indici thesauri ornatius complementum, multa ac varia complectens extra rem indicam sacrarum professoribus profutura, precedida de uma introdução", In: Mediaevalia. Textos e estudos, 31 (2012), pp.135-181. Regis Casarin dedicated to probabilism's theme in Diego de Avendaño: Régis Franco Casarin, "O Probabilismo na Scholastica Colonialis Segundo Diego de Avendaño", Dissertação de Mestrado (Programa de Pós-Graduação em Filosofia da Universidade do Vale do Rio dos Sinos, UNISINOS), São Leopoldo, 2012, 94p.
} 
has complications, either because of the treaties' problems that are so far from our contemporary reality or for other issues inherent to the author's theory. One of these, and I believe to be essential to understand his position on black slavery, is the difficult comprehension of n.204, paragraph VIII, chapter XII, title IX, tome I, of Thesaurus Indicus. In which, after analyses of some authorities' position on this trade he shows four sentences condemning the Ethiopian slavery trade but, in the end, Avendaño says it is possible to justify in some way this trade through seven arguments. This affirmation enables the reader to doubt what would be the author's position on the trade of slaves. Furthermore, over the years, the historiography sometimes regards Avendaño as an abolitionist, in the opposition not only of the trade of slaves but also the institution - as appears in Humboldt's affirmation. Notwithstanding, it is possible to read in some pages where Avendaño says that the black slave has no longer a legal personality ${ }^{12}$, the slave is recognized as an unpleasant man $^{13}$ (in Latin: vilis, vilis, vile) and is good for sale ${ }^{14}$; positions that hardly an abolitionist advocate.

In the present text we attempt to highlight a few points in Avendaño's argument that allow us to consider that the personal Jesuit position would be contrary to the trafficking and trade of Ethiopian slaves that was done at the time, especially if we look at the criticisms he made against the authorities of the time. However, we will hold on that Avendaño did not condemn the institution of slavery as such, accepting certain fair titles of slavery, like other authors of his time. So we propose the following path: first Avendaño's analysis of the Molina and Sánchez positions; and second Avendaño's own arguments on the subject. We will use the first volume of the Thesaurus Indicus, in particular: Title IX, chap. XII, § 8; where the author discusses the trade issue of Ethiopian slaves, text quoted in

\footnotetext{
12 Thesaurus, Tome I, Title V, n.253.

13 Thesaurus, Tome I, Title IV, n.150, n.152; Title IX, n.204.

${ }_{14}$ Thesaurus, Tome I, Title VI, n.24; Tome I, Title, n.176, n.177, n.180, n.194.
} 
the secondary literature as essential to the treatment of black slavery ${ }^{15}$. Finally, we recognize straightaway that this study does not intend to end the discussion or put a definitive answer to it but contribute to the understanding and study of this important author of the colonial period.

\section{Thomas Sánchez and Luis Molina positions' and the Avendaño criticism}

The question about Ethiopian trade is argued by Avendaño in Thesaurus, Tome I, title IX, §8, entitled "on the buying and selling of Ethiopian slaves ${ }^{16 " . ~}$ The theme is according to author: "[...] it is such a dangerous theme for the Christian consciousness that if it only takes the justice standards, it will have something in which to be totally peacefully in such contracts"17. It is appropriate to highlight that title IX, where Avendaño makes his analyses, is dedicated to Consulate Commerce, the regulative American institution responsible for the control of goods and the contracts realized with exterior traders. This already points out the way in which Avendaño treated black slavery: the morality of contracts. It is important to warn that the authors of this time did not question properly the morality of

\footnotetext{
15 According with Ángel Muñoz García, "Diego de Avendaño y la Abolición de la Esclavitud", op. cit., p.142; also mentioned in the "Introducción", Diego de Avendaño, Corregidores, encomenderos, cabildos y mercaderes. Thesaurus Indicus, vol. I, Tít. VI-IX, Traducción Ángel Muñoz García, Pamplona, Ediciones Universidad de Navarra, 2007 [Colección de pensamiento medieval y renacentista, núm.93]. Ángel Losada consider this text in his analyses, asserting it to be essential for the exposition about the theme. Look at: "El Abate Grégorie...", op. cit., p.81.

16 Thesaurus, Tome I, Title IX, Chap.12, §8: "De contractu Aethiopum mancipiorum". According to Tellkamp the Latin term Aethiops, Aethiopis (Ethiopian) was used in this time for nominated people from the Africa, not only the people from Ethiopian. Look at: Jörg Alejandro Tellkamp, "Esclavitud y ética comercial en el siglo XVI", Anales del Seminario de Historia de la Filosofía, 21 (2004), 138.

17 Thesaurus, Tome I, Title IX, Chap.12, §8, n.180: "Modo id tantum adiecerim, rem hanc adeos esse Chrostianis conscientiis periculosam, ut si ad regulas iustitiae aptari debeat, vix aliquid occurrat, quo possit plena securitas in hiusmodi contractu reperiri".
} 
slavery as institution, but the moral problem was, as said by Munõz García, to know if the titles attributed to slaves were done in a fair way ${ }^{18}$.

Saying that, to treat this "dangerous theme for the conscience", Avendaño starts reviewing the positions of some authors, between them: Tomás Sánchez, Luis de Molina, P. Rebello, P. Fragoso and others ${ }^{19}$, before to show his position afterwards. Avendaño gives particular attention to coreligionist authors Tomás Sánchez (n.180-182) and Luis de Molina (n.187194). About Sánchez's position, the author of Thesaurus shows through seven arguments that slavery titles were in general unfair and then the trade is condemnable. A summary of these arguments is shown below ${ }^{20}$ :

[i] the contract of Ethiopian slaves is unjust and carries with it the obligation to return liberty to them; although there are fair titles of slavery, in general they are subjected unfairly ${ }^{21}$;

[ii] the contract would be legal and fair if the traders, when making the transaction looked into the validity of the titles. But it is not what occurs, because in general the care of these titles is superficial22;

18 For Ángel Muñoz García: "el único problema moral de la esclavitud como tal era el de que el título por el que se aplicaba fuera un título justo. Pero la [esclavitud] como tal no era problema moral" (Introducción, op. cit., p.193).

19 The important translation and critical edition of Muñoz García makes possible to say which texts Avendaño refers to, the most important: "Luis de Molina, De justitia et jure; F. Rebello, De obligationibus iustitiae; B. Fragoso, Regimen Republicae Christianae ex Sacra Theologia" (Thesaurus, Tome I, Title VI-IX, footnote 109, p.451). Add the text of P. Sánchez: Consilia seu opuscula moralia, book I, cap. I, doubt 4, which the own Avendaño gives the information (Thesaurus, Tome I, Title IX, Chap.12, §8, n.180).

${ }_{20}$ This exposition follows Avendaño's argument in his Thesaurus. For a precision of arguments in work Sánchez see the critic edition's footnotes by Muñoz García.

${ }_{21}$ Thesaurus, Tome I, Title IX, Chap.12, §8, n.180: "contractationem istam, qua Aethiopes es suis regnis adducuntur, esse iniustam, et cum obligatione restituendi libertatem quia tituli seruitutis communiter loquendo sunt iniusti, licet respectu aliquorum contingat titulum iustum extate. Cum enim qui sint tales ignoretur, non debent iniuste capti, qui multo plures sunt, sua libertate priuari".

22 Thesaurus, Tome I, Title IX, Chap.12, §8, n.181: "Si Mercatores contractantes exactissime examinarent títulos et deprehenderent ese iustos, licita esset contractatio. Hoc tamen ese moraliter impossibile; et diligentiam, quam adhibere communiter dicuntur, omnino superficialem ese pro comperto habetur [...]". 
[iii] the traders that bring the slaves from Ethiopia commit a mortal sin and this require to return liberty to them, apart from some cases where examination confirm the justice of the titles ${ }^{23}$;

[iv] The same occurs with who buys slaves direct from Africa. They commit a sin because not investigated the titles' validity. Nevertheless, if the slave after being sold is repurchased, the new buyer is not required to give the freedom back, because he is unable to enquire about their justice title ${ }^{24}$;

[v] Whoever buys believing in the good faith of the trader does not require restitution the freedom for the slave in case of doubt, when unable to ascertain the truth about the title the new possessor has priority over its ownership ${ }^{25}$;

[vi] However, the person who buys with bad faith or has doubts about the title of capture commits a mortal sin; and if he cannot take away his doubts with probable arguments, he must give back the freedom, as this right prevails on the fact that he has done something in bad faith ${ }^{26}$;

And, the last argument:

${ }_{23}$ Thesaurus, Tome I, Title IX, Chap.12, §8, n.181: "Mercatores qui in magno numero emunt ab aliis, qui ex Aethiopia miseros istos adducunt, peccare mortaliter et ad restitutionem teneri, nisi facta diligentia de iusto titulo captivitatis constet".

${ }_{24}$ Thesaurus, Tome I, Title IX, Chap.12, §8, n.181: “idem ese, quando unus, aut alter emitir a Mercatoribus, qui eos ex Aethiopia addcunt, propter eamdem rationem. Post unam, autem, aut alteram venditionem factam, non teneri ad talem diligentiam, quia iam non est posible cognosci, quonam titulo captus sit et ita diligentia esset superuacua".

25 Thesaurus, Tome I, Title IX, Chap.12, §8, n.182: "Ementem unum, vel alterum bona fide, licet superueniant posteas dubium an fuerit iustes captus, non teneri manumittere, si facta diligentia nequeat veritas deprehendi, quia in dubio melior est conditio possidentis" .

${ }_{26}$ Thesaurus, Tome I, Title IX, Chap.12, §8, n.182: "eum, quia mala fide emit, aut cum dubio de titulo captivitatis, peccare mortaliter et si no possit deponere dubium rationibus probabilibus, teneri manumittere, quia possessio cum mala fide nihil iuvat, quando est alius, qui potius ius habeat, scilicet ipse Aethips, quia habet ius naturale, et possessionem suae libertatis". 
[vii] Sánchez refutes the simple fact that the slaves exposed to public sale eliminate any buyer's obligation to investigate the justice of the slavery title ${ }^{27}$.

Sánchez' position is contrary to the action of buying and selling Ethiopian slaves because he understood that these titles are in general unfair. If there are doubts about the way they were conducted in the slavery regime then the sale must not be realized, because the action lacks moral certainty that would ensure the action has taken place with a secure conscience. However, Sánchez seems to consider the buying of slaves legal in three strict situations: first, it is when the transition occurs with right and proper titles - as appears in sentence [iii]. Second, when the responsible for the trade investigates and confirms the justice of the titles in original place of sale - how we can see at the beginning of sentence three. In this case, the sale can occur with secure conscience and neither the seller nor the customer can be accused of making mistakes - argument [iii]. The third situation is when the purchase was realized without bad faith. In this case, the new owner is not required to give back the liberty to the slave, because he is not able to investigate the justice of the title anymore just believing in the trader's good faith. Then, the right of ownership prevails above the supposed injustice committed to the slave- as appears in the fifth argument. However, this situation is different from that one which occurs with bad faith - for example, when the trader knows that the slavery title is unfair, but he still buys them, acting deliberately bad - In this case, he must return the slaves to liberty, once is sure the injustice of the title.

\footnotetext{
27 Thesaurus, Tome I, Title IX, Chap.12, §8, n.182: "[...] postquam tales publice vendendi exponuntur, non ese obligationem ulterioris inquisitionis circa iustum captivitatis titulem. Sic Doctor ille; ex quibus tamen nihil elici posse, quod favear, si inter se componantur et id quod communiter accidit, attendatur, facile potest ostendi". The doctor mentioned is Michael Palacios that would expose this opinion in his book Praxis theologica de contractibus et restitutionibus, 1585.
} 
It is important here to make a short explanation about the term of obligation (obligatio). It can be understood in two different ways, not exclusive necessarily. The first is about the perspective of the law, where the obligation is incorporated in the contract between the trader and the customer. This conception has origins in the classical jurists, in whom the slavery title has consisted in a title of dominion and full ownership, this means: right of use (ius utendi), right of usufruct (ius fruendi) and right of abuse (ius abutendi) by the buyer of the slave ${ }^{28}$. The second way is the sphere of agent conscience. The elements "good faith" and "bad faith" are intimate nature and they involve not only the subject intention but also the knowledge of the situation itself. Then when a title of slavery is presented as legal and accepted by the legal institutions of society, the obligation to restore freedom to slave can only be imposed by the buyer himself and not by an external coercion by a legal body, for example. The act of give back the freedom would be based on self-imposition of the buyer.

Although the Thesaurus title seeks to discuss the contracts originally, the second approach seems more relevant to philosophical discussion, because Avendaño's critic of the permissions granted by Sánchez are in the sense that the acquisition cannot be made with safe conscience. In the first case, Avendaño understands that:

because it is said that the contract is unfair by the reason that [the opinion], those who are brought prisoners retained the right of freedom; and those who buy from the ones that brought [the traders] cannot apply the greater diligence and therefore cannot acquire them. Thus, after two sales must be said the same as the first, since, the source is addict and known as such. Apart from clear those who buy from Ethiopia, bringing this abundant merchandise, do not bother to inquire

28 Ángel Muñoz García, "Aristóteles; una sociedad imposible sin esclavitud”, op. cit, p.181. 
about the title and much less the next customers. Thus, they cannot own with safe conscience those that were bought"29.

Note that: for Avendaño does not matter how often a slave was sold before, it will not make the legal acquisition and neither the title valid if it was attributed in an unfair way in the beginning ${ }^{30}$. In addition, the general opinion is that the titles are unfair, and the traders are not taking care in investigating them, and even believing in the trader's good faith, they could not buy Ethiopian slaves with a safe conscience.

The second case of the right of ownership prevails above the supposed injustice caused to the slave could be supported because the doubts are favorable to freedom.

When the good faith follows the doubts, even not able to do any investigation in order to find out the truth, the possession is in favor of freedom, because it must be opinion according with what normally happens. It is like, as we say, and the Father [Molina] proves it, the slavery title is generally unfair; therefore, must be judged in accordance with it. [...] Then, in our case, there is not equal probability by both parts only just

\footnotetext{
29 Thesaurus, Tome I, Title IX, Chap.12, §8, n.183: "Patet ex primo, et secundo: quia contractatio iniusta dicitur, et cum onere restitutionis: ex eo quod ii, quid adducuntur, communiter loquendo, ius libertatis retinent; qui autem ab adducentibus emunt, maiorem facere diligentiam nequeunt et ita neque emeres ergo postunam, et alteram venditionem id est dicendum, quod in primas; quandoquidem viriosa est origa, et ut talis cognita. Praeterquam quod manifestum este mentes ab iis, qui ex Aethiopia adducunt copiosam hanc mercem, de inquisitione tituli non curare, et multo minus fequentes emptores, ergo nequeunt, qui emuntur secura conscientia possideri " [my italics]).

3o Silvio Savala mentions how were done the capture in the Africa: "las poblaciones negras menos organizadas, situadas más al interior [da África], fueron objeto de asaltos lanzados por los estados vecinos de la costa, que a menudo se interesaron también por la explotación minera. Los portugueses y los mestizos jugaron un papel importante en este tráfico, y el de esclavos fue destinado esencialmente a las posesiones de América" (Silvio A. Zavala, El mundo Americano en la época colonial. Tomo I. Editorial Porrúa, México 1990, p.159). This act of capturing the people from Africa, especially in Angola and Congo regions, could be took as usually practice in of the time and because this formed the common opinion about the injustice of these titles. A similar opinion can be seen at: Maria Cristina Navarrete Peláez, "Consideraciones en Torno a la Esclavitud de los Etíopes y la Operatividad de la Ley, Siglos XVI y XVII", Historia y espacio 27 (2006), 1-23.
} 
a moral certainty of injustice of the title or a probability that undoes the doubts practicably; so, cannot hold the slave ${ }^{31}$.

Avendaño's critique of Sanchéz' position reveals a more radical attitude. For the first author the doubts about the justice of the slaves' titles remain in cases when Sanchez believed did not exist anymore. Also, it is remarkable to see, as the author of Thesuarus said, the fact that the right of freedom should prevail when there is doubt about the justice of title, even when the buyer does it with good faith.

The position adopted by Sánchez followed what Luis Molina said ${ }^{32}$. Because this Avendaño retakes some Molina's passages and arguments about the trade of Ethiopian slaves in his De justicia et jure (especially in treatise II, Disposition 35). Avendaño adduces six arguments which Molina condemned those transitions. Initially, the author of Thesaurus exposed Molina's four conclusions which the Jesuit said: "the trade of buying slaves of infidels is unfair, unjust and all of these that practice are in a state of eternal damnation"33. But as Sánchez, Molina makes flexible his position to admit some terms ${ }^{34}$ which the slaves' titles can be right and legal, namely: [a] the purchase is legal when the slaves are prisoners of just war; or [b] when the slavery is a punishment of crimes; or also [c] when the father, in extreme poverty, sells his children to avoid their death.

31 Thesaurus, Tome I, Title IX, Chap.12, §8, n.184: “Quando enim post bonam fidem sequitur dubium, licet nulla adhiberi diligentia possit, qua veritas exploretur, possessio stat pro libertate, quia debet iuxta communiter accidentia iudicari; atqui, ut diximus, et probat dictus Pater, communiter titulus servitutis est iniustus; ergo debet iudicari iuxta illud. [...] Atqui in casu nostro non est aequalis probabilitas ad utramque partem, sed moralis certitudo de iniusto titulo, aut talis certes probabilitas, quae dubium sere vincat; ergo nequit seruum possidere" [my italics].

${ }^{32}$ In Avendaño's words: “P. Thomas Sancius, qui quasestionem magis ex professo versaiut post P. Molinam [...]" (Thesaurus, Tome I, Title IX, Chap.12, §8, n.180).

33 Thesaurus, Tome I, Title IX, Chap.12, §8, n.187: "negotiationem ementium mancipia ab indelibus esse iniustam, et iniqum, et omnes eam exercentes esse statu damnationis aeternae".

${ }_{34}$ Thesaurus, Tome I, Title IX, Chap.12, §8, n.187: "Sic ille in quarta conclusione, ubi absolute loquitur tres enim praecedentes sunt conditionales". 
Molina' second argument is the strange affirmation that slavery can be a way to introduce Christianity in those regions, once made with safe conscience ${ }^{35}$. Molina understood this practice can reduce the local barbarism. Then, the result is greater and helps to spread the Christian religion in these regions. However, Molina said: "only will be permissible slavery of these and any other where it appears lighter than the proper light", as said in the third argument ${ }^{36}$.

The fourth and fifth arguments are related to the customer ${ }^{37}$. The fourth says the purchase is made with good faith, but if in the end of transaction, the buyer still has questions the new owner is not obliged to give back the liberty based on part and according to the magnitude of the doubt. However, the fifth argument he says, if after the examination of title, the doubt remains in the buyer, who did in good faith is not obliged to grant the slave freedom.

Lastly, Molina seems to admit that the slaves brought from the Indies can be bought, because the investigation of the titles is Prince and Government's responsibility ${ }^{38}$.

Even with the exceptions admitted by Molina, about the existence of fair titles of slavery and some specific situations, the Jesuit position is against this negotiation. Avendaño accepted his terms, but this did not stop him to make some commentaries to Doctor Molina. For example, by commenting on the second argument, when Molina accepts the slavery as a means for the introduction of Christian religion, Avendaño said,

\footnotetext{
35 Thesaurus, Tome I, Title IX, Chap.12, §8, n.188: "Secundum, dum alia via ad fidem Christianam inducendam in illas regiones non suecurrit, sauendam esse negotiationi ipsi quantum salua conscientia fieri potest; quiam sic Magnum illus bonum, minimes alias consequentur, es barbaria educti, in quam brutorum potius, quam hominum more vivere comperiuntur".

${ }_{36}$ Thesaurus, Tome I, Title IX, Chap.12, §8, n.188: “[...] quam si luce clarius eam iustam esse constet [...]”.

37 Thesaurus, Tome I, Title IX, Chap.12, §8, n.189.

38 Thesaurus, Tome I, Title IX, Chap.12, §8, n.189: “[...] quia non spesctat ad subditos examinare an merces licites asportentur in regnum, sed as Principem; cum ergo ille videatur probare, non est circa id scrupulosius indagandum".
} 
It can be accepted, but with only one condition, to know it was done with safe conscience. Christ does not want to consolidate the faith by indignities. On the other hand, who works in this business is not motived by faith, but by the income. Then, even if they knew that those involved in the transfer would not be Christians, they still will take them. Therefore, the injustices caused towards the benefit of faith, which follow subsequently, should not be considered equivalent to freedom, which is more precious than gold 39 .

In the comments to Molina's third argument Avendaño stated that the "affirmation is, indeed, said pious and wisely" 40 , but at the same time he admitted that the trade realized with safe conscience is not necessary a title lighter than the light, just probability title is enough ${ }^{41}$. Here Avendaño's probabilism appears strong, in the same way of his analyses on Sanchez' position when Avendaño condemned the trade because it could not be done under safe conscience, remaining with the general opinion about the injustice of these titles. And here, most similarly, Avendaño said: "the Angolans captured in war could not be enslaved, because the justice of this war is not clearer than the light"42.

39 Thesaurus, Tome I, Title IX, Chap.12, §8, n.191: “[...] sed cum addita praecautione, quantum sciticet salus ad conscientiad fueri possit. Non vult Christus fidem iniuriis stabiliri; cum alias negotiationi isti vacantes, fidei negotium non agant, sed lucri studio ad illam penitus moveantur. Unde siscirent eos, quos asportant, Christianos minime futuros, similiter asportarent: non ergo ipsis circa auro pretiosiorem libertatem irrogatae iniuriae ex fidei commodo, quod accessorie sequitur, compensabiles censeantur. Sic infidelium filii inuitis parentibus nequeunt baptizari" [Italics in original text].

40 Thesaurus, Tome I, Title IX, Chap.12, §8, n.191: "Quod autem in Tertio habetur, est quidem pies et sapienter dictum $[\ldots . .$.$] .$

${ }_{41}$ Thesaurus, Tome I, Title IX, Chap.12, §8, n.191: "[...] sed certe non esse necessarium pro servitute permittenda, ut luce clarior illius titulus sit, ex priori est pronuntiatio deducendum. Cum enim negotiationi favendum sit, quantum salvas conscientias fieri possit, non est certes necessarius titulus luce clarior, cum sussiciat esse probabilem; tuta enim conscientia potest probabilis sententia teneri circa titulum huismodi, sicut circa alia, et de bello est satis communis sententia inter Recentiores".

42 Thesaurus, Tome I, Title IX, Chap.12, §8, n.191: "Et veros si titulus luce clarior ad servitutem permittendam requiritur, bello capti Angolani non poterunt in servitutem redigi, quia justitia illius belli no est luce clarior". 
Avendaño goes further than Molina in his comments and this can be observed in the last three. First, the author of Thesaurus admits if there is doubt on the trade done with good faith the liberty should be return to slaves, even in a gradual manner like reducing the bonds with a better deal or even paying a salary to slaves, allowing them to buy their freedom ${ }^{43}$. About the fifth argument, Avendaño understood that it was difficult to believe in traders base on good faith, when their bad faith is recognized publicly ${ }^{44}$. And, last, he pointed out a weakness in Molina's thesis. He emphasizes the traders cannot sell because the transaction is unjust, nor who bought from them, because it must be applied for the same reason: the title is unfair ${ }^{45}$. Moreover, Avendaño did not "accept" Molina's position about the Prince should find out the status of all commercial relations. He said:

[...] nor convinces what [Molina] says, namely that the analysis of these goods does not correspond to the subjects but to the Prince [...]. The Prince allows this, because it does not contain a manifest injustice for him; or, if present, there is a reason for him to allow it, in order to avoid greater evil. But the vassals [...] cannot promote such negotiation with purchases, to be their accomplices, nor approve it in words, or in fact too"46.

Avendaño also criticizes Molina regarding the distinction of buying places, whether in Africa or in the ports of India where the purchase cannot be made with safe conscience, due to the knowledge that many slaves were sentenced unfairly to slavery and sold by traders. Avendaño concludes with his comment: "from here, and other expressions of

\footnotetext{
43 Thesaurus, Tome I, Title IX, Chap.12, §8, n.192.

44 Thesaurus, Tome I, Title IX, Chap.12, §8, n.193.

45 Thesaurus, Tome I, Title IX, Chap.12, §8, n.193.

46 Thesaurus, Tome I, Title IX, Chap.12, §8, n.194: "Nec satisfacit, quod ait ad subditos scilicet examen de huiusmodi mercibus non spectare, sed ad Principem, [...]. Princeps ergo permittit, quia illi de manifestas inustitias non constat, vel si constat, rationes habet ut permittat, maiorum damnorum evitandorum caussas: subditi autem, [...] nec permissionis jus habent, nequeunt negotiationem dictam, dum emunt, fovere, illius esse confortes, et non tantum verbis, sed factis etiam approbare".
} 
this great Doctor concluded that this negotiation is reprehensible; so Portuguese traders cannot buy, and therefore sell"47.

Now we are ready to advance with Diego de Avendaño's position, second part of this study.

\section{Avendaño's position on the Ethiopian trade and slavery in general}

The analyses about Sanchez and Molina's positions can serve to understand some elements about the position of the Thesaurus' author. In both, Avendaño states that the process of buying cannot be done with safe conscience, because it is the general opinion that the slavery titles are attributed unfairly. Furthermore, if the doubt persists the slave must be returned to liberty, even when the purchase was realized in good faith. This restitution can be realized partially, as Molina suggested, through work reduction and a better treatment. Moreover, for Avendaño, it does not matter if the sale occurred publicly or if the negotiation has already been started elsewhere - either in Africa, in European ports or West Indies - if the original title was attributed unfairly then who does the trade commits a mistake and must give back the liberty to the slave, because the purchase has not occurred with safe conscience. Nevertheless, it is important to highlight how many times Avendaño appeals for general opinion, which invoke that the slavery title is unfair and that is enough to condemn this practice.

These considerations are reinforced by Avendaño himself when he begins his position in n.203. He makes this by invoking five short and clear arguments, however not free of difficulties. So, we can separate it into two groups: (a) on one side the four arguments (i-iv) condemning the trade; (b) on the other hand the fifth argument ( $v$ ) which justifies this practice. It is right. In his position Avendaño provides an argument

47 Thesaurus, Tome I, Title IX, Chap.12, §8, n.194: "Ex his ergo, et aliis Doctoris tanti pronuntiatis habemus negotiationem istam esse damnabilem, ut neque emere Lusitani Mercatores queant, neque consequenter vendere". 
that justifies this trader at the same he condemn it. Why does he do it? It is a mystery. I believe because of his probabilism. But first, we need to show these two groups of arguments.

The first group can be exposed in this way, paraphrasing the Thesaurus:

I. Many deals made in those regions were illegal and unfair, and involves repayment obligation ${ }^{48}$;

II. The purchase of the slaves brought from Africa done by the traders is not legal, whether in India or in Europe ${ }^{49}$;

III. Also, it was illegal to buy one or two slaves when there was doubt, whether the sale took place publicly or was renegotiated, if in both cases the right of the titles was ignored ${ }^{50}$;

IV.The purchase was illegal even when the slave had several owners, because the title of slavery did not improve with multiple owners ${ }^{51}$.

These four arguments reinforced what he said so far. And, if Avendaño had not written the fifth statement in n.204, his position would be clear: a theorist against the Ethiopian slave trade. But Avendaño wrote the fifth argument (in paragraph n.204) and in his words: "the purchase in India and in Europe somehow [aliqua] can be justified ${ }^{20}$ and showed seven arguments that supported this affirmation, in his own words:

48 Thesaurus, Tome I, Title IX, Chap.12, §8, n.203: "Dico primo: negotiatio dicta, secundum maiorem partem mancipiorum qui in illis partibus emuntur, est illicita, iniusta et cum onere restitutionis".

49 Thesaurus, Tome I, Title IX, Chap.12, §8, n.203: "Mancipiorum copiam a Mercatoribus, qui ea ex Africae regionibus asportant non est dicitum emere in Indiis, et Europa. Hoc etiam ex dictis constat".

50 Thesaurus, Tome I, Title IX, Chap.12, §8, n.203: "Dico tertio; neque unum aut alterum mancipium licet emere ex eisde, stante suspicione ob fundamenta dicta. [...] et ratio est clara: quia de uno et altero na sit iusto titulo emptur, ignoratur sicut copia as portatorum".

51 Thesaurus, Tome I, Title IX, Chap.12, §8, n.203: “Dico quarto. Generaliter loquendo et iuxta principia dicta, non licete emere huismodi mancipia, etiam si plures dominos habuerint. Probatux quia ex multiplicatione dominorum non melioratur titulus servitutis".

52 Thesaurus, Tome I, Title IX, Chap.12, §8, n.204: “Emptio dicta in Indiis et Europa iustitficari potest aliqualiter". 
first, because some doctors, even though some of them inconsequently with his own sentence, state that the purchase is not clearly condemnable, even taking his side as P. Molina [...]. Second: for thus it is accepted as a common practice by all states: the bishops and religious men, which act without any scruples. Third, because the King not only allows it, but also buys and sells them; whose example his vassals can follow freely [...]. Fourth: because the Bishops, as per owner's example, excommunicate those who steal slaves, considering it their appropriated right. Fifth, because, according to someone there are people born to serve others [...]. Sixth, because they are so needed in West Indies and this republic cannot stand without them. And as they are the vilest within the men, can be overlook any requirement of Gentiles law [ius gentium], so that regions of the West Indies, whose conservation of Christian interest, not decayed his state as necessary to recognize it. Finally: because you cannot prevent their transfer to West Indies, once our kings have urgent reasons to allow it and even authorizes it ${ }^{53}$.

This set of arguments justifies the Ethiopian slave trade, opening up the prospect for a completely opposite view to the speech that the Jesuit made Title IX, Book I, of the Thesaurus. But why did Avendaño write this?

53 Thesaurus, Tome I, Title IX, Chap.12, §8, n.204: "Primos: quai Doctores aliqui, licet eorum quidam inconsequenter ad suam iplrom doctrinam, eam non esse apertes damnabilem affirmant, immos et illi fauent, ut P. Molina [...]. Secundos: quia ita est communi praxi receptum, quase omnes status complectitur: Episcopos, Religiosos, sine ullo in hac parte scrupulo procedentes. Tertios: quia Rex non solum permittit, sed et ipse emit, et vendit, cuius exemplum sequi integrum est vasallis, cum in eo debeant iustitiae exempleria: praelucere. Quartos: quia Episcopi contra furantes mancipia excommunicationes fulminante ad dominorum instantiam; eorum ius certum reputantes. Uintos, quia cum mancipia ista videantur ad serviendum nata [...]. Sextos quia pro Indiis adeos sunt necessarii, ut sine illis stare Respublica ista nequeat. Cum ergo villissimi isti inter homines sint, dispensari cum aliquo requisito iuris gentium potest, ne Indicae regiones, quarum conteruatione res Christiana agitur, abe o cadant statu, qui adeos necessarius comprobacurc. Tandem: quia asportatio eorum in Indias nequit impediri, quia ad eam permittendam, imos et auctorizandam, Reges nostri urgentes habent rationes". 
How can we conciliate the passage above with the rest of the text which we have seen condemn this transaction?

First, it should be noted that this surprise has caused repercussions previously. The Friar Epifanio of Morains OFM (1644-1689) on Avendaño's fifth statement, said:

I, in fact, had approved the doctrine, but thinking better when observed the fifth statement swerved, I was surprised that a person with a doctorate destroys and eradicates what his prepared, founded and built so well. Moreover, far from me follow this path which deviates from the straight truth and justice ${ }^{54}$.

But, would Avendaño destroy what he has prepared? Well, I believe he did not necessarily. I think that Avendaño exposes two sides on the same moral dilemma and left the reader to decide. This position would be consistent with his probabilism ${ }^{55}$ (Avendaño was also an opinion leader).

54 "Enimvero, recte sentien, probaveram doctrinam, sed videns declanationem in quinto dicto, miratus sum virum doctorem destruere et eradicare quae bem plantaverat, fundaverat, aedificaverat. Sed absit a me talem viam sequi, declanantem a recta semita veritatis et iustitiae" (Epifanio de Moirans, Servi Liberi seu Naturalis Mancipiorum Libertatis Iusta Defensio, op. cit., p.167).

55 The probabilism and the casuistic were part of the Jesuit's moral doctrine. For Bacigalupo: "Los jesuitas fueron bien conocidos por su doctrina moral, que sostenía algo así: Si es lícito seguir una opinión probable que ha sido concebida de forma especulativa como probable sin arriesgar ningún error lógico, entonces también puede ser lícito seguir en la práctica una sólida opinión probable sin correr el riesgo de cometer pecado mortal” (Luis Bacigalupo, “Las razones del probabilismo. Una exposición sucinta de sus fundamentos" Sílex 3 (2014), p.51). The probabilism has origin in the classic period and implication in many sphere of philosophy. In the context of moral, the probabilism argues that it is not possible to have the apodictic knowledge of rules and principles, only moral beliefs based on probable opinions. Due to the contingency of action, the agent is susceptible to doubt about the legitimacy of his action or at least not culpable, the probabilism suggests that just a probable opinion, not necessarily the most probable, to overcome doubt and ensure action with safe conscience. This process is not simple as it can be assumed at first sight. Bacigalupo points out that the probability of an opinion is associated with its internal elements (according to their rationality and the possibility to be feasible) and its extrinsic elements be supported by any authority or the civil code, for example. More details about the epistemological status of probable opinions look at: Luis Bacigalupo, "Las razones del probabilismo...", op. cit., 43-57. For a general introduction look at: Ángel Muñoz García, “Introducción”, op. cit., p.63-75; and for an introduction in Avendaño's probabilism see: Roberto Pich, Renata Floriano and Pablo Pimentel, “Diego de Avendaño sobre 
Faced with a moral dilemma, using the probabilism's procedure ${ }^{56}$, would suffice to find a probable opinion that satisfies some conditions ${ }^{57}$ to ensure the action with safe conscience. It is important to remember here when he commented Molina's position, Avendaño said the title of slavery was not necessary to be clear in the light of justice, but only probable. Therefore, when some authorities stand against the slave trade it is also possible to find arguments which supported this business transaction. It could be argued if these arguments are strong enough for pro-condemnation of trade, but Avendaño did not make them, staying faithful to his probabilism.

This exit is not unknown. Muñoz García argued this in a critic edition of Thesaurus Indicus ${ }^{8}$ and retakes in the 2007 edition: "even certain of his repel, [Avendaño] accepts the probabilism. This is the point that would save to honor of his solution: Avedaño victim of his own principles and convictions ${ }^{59}$ ".

If (and here "if" is important) Avendaño used probabilism to deal with slave dilemma then we have a realistic answer to understand the reason why he wrote the controversial fifth argument. Now, can we state

\footnotetext{
a opinião provável - Tradução e edição simplifi cada de Diego de Avendaño S.J. (1594-1688), Auctarium Indicum seu Tomus Tertius ad indici thesauri ornatius complementum, multa ac varia complectens extra rem indicam sacrarum professoribus profutura, precedida de uma introdução", In: Mediaevalia. Textos e estudos, 31 (2012), pp.135-181. And also Régis Franco Casarin, "O Probabilismo na Scholastica Colonialis Segundo Diego de Avendaño", op. cit., 94p.

${ }_{56}$ This procedure, in general, can be summarized this way: 1 . To act it must be certain about the morality of the action; 2. Lacking certain, there are only opinions; 3 . Either act or not act imply moral responsibility; 4 . Then, to select between both options, when the certain lacks, must be decided base on the probable opinions; 5 . On the other hand, an opinion, even the most probable, it is not certain; 6 . It follows, therefore, a probable opinion - cannot be the most probable opinion. In practice, it will get the necessary certain for act with "safe conscience", which Avendaño said. (According with Régis Casarin, "O Probabilismo na Scholastica Colonialis Segundo Diego de Avendaño", op. cit., p.12; and p.43).
}

57 A probable opinion must meet at least three conditions: 1- must be rational and in accord with the laws of logic; 2- should not imply in any absurd; 3- should not contradict Scripture, tradition, the Church Fathers, or a positive law (Luis Baciagalupo, "Las razones del probabilism...", op. cit., p.52).

58 Diego de Avendaño, Derecho, Consejo y Virreyes de Indias. Thesaurus Indicus, vol. I, Tít. I-III, Edición, introducción, texto y traducción de Ángel Muñoz García, Pamplona, Ediciones Universidad de Navarra, 2001, p.166-169. [Colección de pensamiento medieval y renacentista, núm. 16].

59 "A pesar de seguro que está en su rechazo, acepta el probabilismo. Éste es el punto que pudiera salvar la honorabilidad de su solución: Avendaño víctima de sus propios principios y convicciones” (Ángel Muñoz García, “Introducción”, op. cit., 2007, p.205). 
Avendaño was against the black slavery? If we look at his criticism made to Sánchez and Molina, Avendaño appears to have a more radical approach than his predecessors, saying the trade was unfair and been against not only the sales done in West Indies, but in Africa too. Moreover, I believe we can add two more reasons that provide strength to Avendaño's personal idea was against the trade, namely: (a) the extension and the amount of arguments that Avendaño takes to show that this business transaction is unfair and cannot be made with safe conscience, longer than the fifth argument; and (b) the final appeal of paragraph VIII (n.205).

Regarding the first point, it is reasonable think Avendaño was against of this transaction. He brings, from the beginning, positions in favor of the trade and at the same time criticized them and appointing inconsistencies in arguments of other authorities. In the same way goes the second point. Does not make sense to appeal for something that not believe in.

There will be just a few who accept in practice what we have discussed and carefully establish about the injustice of this negotiation, and preferred to join this last assertion; as the previous may have set in vain. But certainly, I believe, the good judgment could not argue that, as in Scripture, not fought for truth and the battled for justice. Then, is necessary to judge also the many authors that we claim as supporters of the same cause. Without forgetting that what we have said can serve in addition to the owners to treat these slaves more humanly, understanding that the right of domain that they believe to have about it is so doubtful that is necessary to walk almost with eyes closed to resist when passing the light of truth ${ }^{60}$.

\footnotetext{
60 Thesaurus, Tome I, Title IX, Chap.12, §8, n.205: "Quae ergo as nobis pro iniustitia negotiationis huius ostendendas no leviter disputata et stabilita sunt, erunt pauci qui practices complectantur, ultimae huic Assertioni libentius inhaerentes; unde et videri possunt illa superuacues constituta. Sed certes pro veritate pugnasse, et agonizasse pro iustitia, ut Scriptura loquitur non poterit, ut credo, rectes sentientibus non probari. Sic enim et in scriptorum multis est cernere, quos pro eiusdem, cause defensione militantes allegauimus. Quin etiam, qui as nobis dicta deseruire praetereas poterunt, ut mancipiorum istorum domini humaniuus cum ipsis agant, scientes ius
} 
The passage above in addition to the four first arguments seems to me a strong indication to Avendaño's personal position was against trade of Ethiopian slaves.

Lastly, it is important to know if this is enough to consider him as a theoretical abolitionist, i.e. against the slavery at all.

Losada, who considers Avendaño as a theorist against black slavery, understands the text Popes bulla Sublimis Deus (1537) by the Pope Paul III as key text for his argument contrary to slavery ${ }^{61}$. The document has great importance on the slavery discussion, because Pope Paul III condemned the slavery regime imposed by Spaniards on aboriginal people from America. He claimed these men were able to receive the faith and they would not be deprived of their goods nor their freedom. However, in the §8, title IX, Avendaño did not mention this important text directly. Then, it could difficult to say that this text is the groundwork for Avendaño's treatment of the Ethiopian slaves' discussion (which is a different discussion of Indian slavery).

Another author who must be mentioned here is Muñoz García. In his paper "Diego de Avendaño y la abolición de la esclavitud" (2009), after he shows all Avendaño's arguments about on black slavery, he reviewed his position in the paper of 2007 (mentioned before). Now, going further than just saying that Avendaño was against the trade of slaves ${ }^{62}$, Muñoz García defends Avendaño's personal position as being against slavery as institution. According to Muñoz García, the reasons behind why Avendaño did not shows his personal position are: (i) he used a rhetorical strategy to not alert his opponents and avoid confrontation with them directly, once he has been inside the positivist ambient, "encrypting" his position against

dominii, quoa in ipsos se habere existimant, esse adeos dubium, ut opus sit in re ista, ne lumen veritatis obsistat, clausis feres oculis ambulare".

61 His position can be look at two works: Ángel Losada, "El Abate Grégoire, Lector de los Humanistas y Juristas Españoles...”, op. cit., 1989, p.82. Ángel Losada, “Diego de Avendaño S.I. moralista y jurista, defensor de la dignidad humana de indios y negros en América", Missionalia Hispanica 15, (1982) p.1-18.

62 Ángel Muñoz García, “Diego de Avendaño y la Abolición de la Esclavitud”, op. cit., 2009, p.32. 
slavery $^{63}$. (ii) For this, Muñoz García thinks that the reasons showed at fifth proposition would not configure as "reason for arguments". For him, (iii) at any moment, Avendaño includes himself in the defense of this position, taking care to make clear that the defenders are others ${ }^{64}$. And because he was a defender of the probabilism, he accepted the existence of the other probable opinions, even he did not agree with them; and how he was casuistic and a defender of the positive law he also accepted that the morality of these contracts should fall, even against his convictions, in the king's will, in line with the positivist ambient that prevailed at the time ${ }^{65}$.

But Muñoz García goes further. He says the argument of the necessity of slavery would hide true Avendaño's thought ${ }^{66}$, once to use an argument from the classic Roman law he would go with the pretext to show that this transaction would not respect the precepts of natural law, because men are slaves only due to social condition, not by nature. Then, according to Muñoz García, Avendaño invites his readers to leave the legal support that justified slavery: the ius gentium; once no law could invalidate the natural law, which states all men are equal and born free.

In second part of Muñoz García' proposal seems to make an interesting attempt to try to answer definitely the question if Avendaño was opposed to slavery at all or not. First, the initial part what Muñoz said supports our position. He exposes both arguments about the slave trade as required his method, even appearing to have as personal idea the trader cannot do with safe conscious. But the second part brings some difficulties. Why did Avendaño not mention that slavery was contrary to natural law when he showed the authorities' arguments and his first four statements? Furthermore, why did Avendaño not criticize the existence of justice titles of slavery when he made his comments about Sánchez and Molina

\footnotetext{
63 Ángel Muñoz García, “Diego de Avendaño y la Abolición de la Esclavitud”, op. cit., 2009, p.24.

64 Ángel Muñoz García, “Diego de Avendaño y la Abolición de la Esclavitud”, op. cit., 2009, p.25.

65 Ángel Muñoz García, “Diego de Avendaño y la Abolición de la Esclavitud”, op. cit., 2009, p.25.

66 Ángel Muñoz García, “Diego de Avendaño y la Abolición de la Esclavitud”, op. cit., 2009, p.25.
} 
positions? It seems to me he could have had the opportunity to show, even covering his personal conviction. And in these cases, we cannot accuse the probabilism theory blocked him from making criticisms of the authorities.

In addition, it is known that legal slavery, permitted by the ius gentium, sometimes was not contrary to the precepts of natural law. For example, Domingo de Soto ${ }^{67}$ in his Justitia et iure (book IV, question II, article II), when speak about the possibility of a man can exercise power over another, mentioned slavery does not annul exactly what the natural law said. Soto's thesis says that the natural law does not prohibit slavery institution as a punishment due to sin and the needs of men ${ }^{68}$. The Soto's thesis can be debated but is not our aim here. What these show is the fact that there were important theorists of Avendaño's period who argued that slavery could exist and would not be contrary to the precepts of natural law - this seems to me the case mentioned by Molina, from slavery due to extreme poverty, because it is better to become a slave than to die, respecting the natural law's precepts by conserving life.

However, if Muñoz is right (and he can and has all authority to be) how to explain the other Thesaurus' passages where Avendaño mentioned that the Ethiopian' slaves would be merchandises and would have a certain value ${ }^{69}$; and the passages where he said that the slaves were vile

\footnotetext{
${ }_{67}$ Domingo de Soto, De lustitia et iure libri decem, Tomo Segundo, libros III-IV, volumen II, Instituto de Estudios Políticos, Madrid, 1968.

68 Thomas Aquinas mentioned that natural' slavery does not exist in absolute terms, only in according with the utility for the society: "Ad secundum dicendum quod hunc hominem esse servum, absolute considerando, magis quam alium, non habet rationem naturalem, sed solum secundum aliquam utilitatem consequentem, inquantum utile est huic quod regatur a sapientiori, et illi quod ab hoc iuvetur, ut dicitur in I Polit. Et ideo servitus pertinens ad ius gentium est naturalis secundo modo, sed non primo"(Summa Theologiae secunda pars secundae partis a quaestione $L V I I$ ad $L X$, Textum Leoninum Romae 1897 editum ac automato translatum a Roberto Busa SJ in taenias magneticas denuo recognovit Enrique Alarcón atque instruxit, q. 57, a. 3, ad 2).

${ }_{69}$ For example: Thesaurus Indicus, Tome I, Title IX, Chap. IV, dif. III, n.43: "Potest autem specialiter accidere, quando ad emenda AEthiopica mancipia ad praediorum culturam necessaria, aliquis destinatur. Ubi etiamsi ille Religiosus sit, et per se vendat, videtur sine gravi culpa stare posse, quia venditio talis respondet emptioni, quae non directes od lucrum; sed ob commoditatem comparandi necessaria celebrata est: [...] Quod et potest cuilibet alteri Ecclesiastico applicari". See also: Thesaurus Indicus, Tome I, Title IX, §7, n.177: "Dico septimo, etiamsi fornaces dictae non construantur pro aedificiis propriis Eccleciasticorum; sed in eorum terries ad quaestum ex eisdem
} 
and dishonorable men ${ }^{70}$, if he has had the personal conviction contrary to slavery at all? These passages would be only a repetition of the discourse of that time and not of Avendaño's position? For me, for now, it seems better to admit that Avendaño did not condemn slavery at all. He spooked about the black slavery and the arguments around this issue, but he did not discuss the slavery institution.

\section{Final Considerations}

If Avendaño's position does not seem clear because of the controversial fifth affirmation it seems to me that there are reasons to believe that the author of the Thesaurus condemns the trade and the trafficking of Ethiopian' slaves to the Indies, when we look at the treatment that the author gives the topic. He condemned this trade in West Indies and the origin country of the slaves, because in both cases the common opinion is the same: the titles of these slaves are attributed unfairly. In addition, Avendaño appears to be convinced that the doubt of the title will continue to a certainty degree, even if the buyer examines them at the time of purchase, because it remains probable opinion that most of the titles are assigned unfairly; and hardly the buyer finds reliable evidence to restore it, then shall remain with the general opinion: the injustice of these contracts. Thus, the slave trade in Africa could not be done with safe conscience, not leaving anything but the moral certain of the injustice of the purchase and sales title.

This position does not weaken with the author's statement about the possibility to justify this trade. I understand what occurs due to the probabilism applied in the treatment of this question. This is the motive why he quoted

\footnotetext{
faciendum, et mancipiorum ministerio, non videtur in eo quidquam Canonica lege prohibitum. Id probo ratione nuper adductas; quia in eo negotiation propria nos est, cum non sit emptio, et venditio rerum sine earum mutatione". Look at: Thesaurus Indicus, Tome I, Title VI, §7, n.24 70 Look at: Thesaurus Indicus, Tome I, Title VI, Chap. XVII, n.150: "Veres niger, et mancipio similis AEtiopico, cui honor nullus debeatur". See also: Thesaurus Indicus, Tome I, Title VI, Chap. XVIII, §1, n.152. It is possible reader on Theasurus the slaves without legal person: Thesaurus Indicus, Tome I, Title V, Chap. XXVIII, n.253.
} 
this second group of probable arguments that circulated at the time, letting the reader decides which of the probable opinions to join. How Avendaño addresses the issue, being careful with the exam of opinions against trafficking and the final appeal in n.205, seem to indicate that the personal position of Avendaño would be against the traffic of Ethiopian slaves.

Finally, with regard to Muñoz position (i.e., Avendaño condemned the slavery as whole) a prudent judgment of any beginner student would accept it because he has all the prerogatives and authority to sustain it. Even defend Avendaño appears to be against the black slavery, I am not convinced he doomed the institution as whole. For this bis conclusion, it is necessary to examine the other books of Thesaurus Indicus, something needs to be done in the next steps of this investigation.

\section{References}

BACIGALUPO, L. Las razones del probabilismo. Una exposición sucinta de sus fundamentos. Sílex, v. 3, p. 43-57, 2014.

CASARIN, R. F. O Probabilismo na Scholastica Colonialis Segundo Diego de Avendaño. Dissertação de Mestrado (Programa de Pós-Graduação em Filosofia) - Universidade do Vale do Rio dos Sinos, UNISINOS, São Leopoldo, 2012. 94 p. https://doi.org/10.21115/jbes.v8.n2.p108-117

DIDACVS DE AVENDAÑO. Thesaurus Indicus seu Generalis Instructor pro regimine conscientiae, in iis quase ad Indias spectant. Tomus Primus, Ea continens, quae ad civilem praesertim conducunt Gubernationem. Antuerpiae. 1668.

DIEGO DE AVENDAÑO. Corregidores, encomenderos, cabildos y mercaderes. Thesaurus Indicus, vol. I, Tít. VI-IX, Traducción Ángel Muñoz García. Pamplona: Ediciones Universidad de Navarra, 2007. (Colección de pensamiento medieval y renacentista, n. 93). https://doi.org/10.1086/ahr/78.2.454

DIEGO DE AVENDAÑO, Derecho, Consejo y Virreyes de Indias. Thesaurus Indicus, vol. I, Tít. I-III, Edición, introducción, texto y traducción de Ángel Muñoz García. Pamplona: Ediciones Universidad de Navarra, 2001. (Colección de pensamiento medieval y renacentista, n. 16). https://doi.org/10.1086/ ahr/78.2.454 
DIEGO DE AVENDAÑO, Oidores y oficiales de hacienda: Thesaurus Indicus, vol. I, Tít. IV y V, Volumen 1, Traducción Ángel Muñoz García. Pamplona: Ediciones Universidad de Navarra, 2003. (Colección de pensamiento medieval y renacentista, n. 54). https://doi.org/10.1086/ahr/78.2.454

DIEGO DE AVENDAÑO. Thesaurus Indicus, Introducción, texto y Traducción de Ángel Muñoz García. Pamplona: Ediciones Universidad de Navarra, 2001, p. 13-53. (Colección de Pensamiento Medieval y Renacentista, n. 16). https:// doi.org/10.1086/ahr/78.2.454

DOMINGO DE SOTO. De lustitia et iure libri decem, Tomo Segundo, libros III-IV, volumen II. Madrid: Instituto de Estudios Políticos, 1968.

EPIFANIO DE MOIRANS, Servi Liberi seu Naturalis Mancipiorum Libertatis Iusta Defensio. Madrid: Consejo Superior de Investigaciones Científicas, 2007.

GARCÍA, A. M. Diego de Avendaño. Filosofía, moralidad, derecho y política en el Perú colonial. Lima: Fondo editorial de la UNMSM, 2003, pp.29-61.

GARCÍA, A. M. Diego de Avendaño y la Abolición de la Esclavitud. Solar, Lima, v. 5, p.133-162, 2009.

GARCÍA, A. M. "Aristóteles; una sociedad imposible sin esclavitud". In: Diego de Avendaño, Corregidores, Encomenderos, Cabildos y Mercaderes. Thesaurus Indicus, vol. I, Pamplona: Ediciones Universidad de Navarra, 2007. (Colección de pensamiento medieval y renacentista, n. 93). p. 123-168.

GARCÍA, A. M. "Introducción", Diego de Avendaño, Corregidores, encomenderos, cabildos y mercaderes. Thesaurus Indicus, vol. I, Tít. VI-IX, Traducción Ángel Muñoz García, Pamplona, Ediciones Universidad de Navarra, 2007. (Colección de pensamiento medieval y renacentista, n. 93). https://doi. org/10.1086/ahr/78.2.454

LOSADA, Á. Diego de Avendaño S.I. moralista y jurista, defensor de la dignidad humana de indios y negros en América. Missionalia Hispanica, Madrid, v. 15, p.1-18, 1982.

LOSADA, Á. El Abate Grégoire, Lector de los Humanistas y Juristas Españoles de los siglos XV a XVII Fuentes ideológicas españolas de la revolución francesa. Historia Mexicana, v. 39, p.71-88, 1989.

PELÁEZ, M. C. N. Consideraciones en Torno a la Esclavitud de los Etíopes y la Operatividad de la Ley, Siglos XVI y XVII. Historia y espacio, v. 27, p. 1-23, 2006. https://doi.org/10.25100/hye.v2i27.4567 
TELLKAMP, J. A. Esclavitud y ética comercial en el siglo XVI. Anales del Seminario de Historia de la Filosofía, Madrid, v. 21, p. 135-148, 2004.

ZAVALA, S. A. El mundo Americano en la época colonial. Tomo I. México: Editorial Porrúa, 1990. 